\title{
Lagos Bat Virus, an Under-Reported Rabies-Related Lyssavirus
}

\author{
Jessica Coertse $^{1,2} \mathbb{D}$, Marike Geldenhuys ${ }^{2} \mathbb{D}$, Kevin le Roux ${ }^{3}$ and Wanda Markotter ${ }^{2, *(\mathbb{D})}$ \\ 1 Centre for Emerging Zoonotic and Parasitic Diseases, National Institute for Communicable Diseases of the \\ National Health Laboratory Services, Sandringham 2192, South Africa; jessicac@nicd.ac.za \\ 2 Centre for Viral Zoonoses, Department of Medical Virology, Faculty of Health Sciences, University of Pretoria, \\ Pretoria 0001, South Africa; marike.geldenhuys@up.ac.za \\ 3 Epidemiology Unit, Allerton Veterinary Laboratory, Pietermaritzburg, KwaZulu-Natal 3200, South Africa; \\ Kevin.LeRoux@kzndard.gov.za \\ * Correspondence: wanda.markotter@up.ac.za; Tel.: +27-12-319-2353
}

check for updates

Citation: Coertse, J.; Geldenhuys, M.; le Roux, K.; Markotter, W. Lagos Bat Virus, an Under-Reported Rabies-Related Lyssavirus. Viruses 2021, 13, 576. https://doi.org/ $10.3390 /$ v13040576

Academic Editor: Laurent Dacheux

Received: 26 February 2021

Accepted: 25 March 2021

Published: 29 March 2021

Publisher's Note: MDPI stays neutral with regard to jurisdictional claims in published maps and institutional affiliations.

Copyright: (c) 2021 by the authors. Licensee MDPI, Basel, Switzerland. This article is an open access article distributed under the terms and conditions of the Creative Commons Attribution (CC BY) license (https:// creativecommons.org/licenses/by/ $4.0 /)$.
Abstract: Lagos bat virus (LBV), one of the 17 accepted viral species of the Lyssavirus genus, was the first rabies-related virus described in 1956. This virus is endemic to the African continent and is rarely encountered. There are currently four lineages, although the observed genetic diversity exceeds existing lyssavirus species demarcation criteria. Several exposures to rabid bats infected with LBV have been reported; however, no known human cases have been reported to date. This review provides the history of LBV and summarizes previous knowledge as well as new detections. Genetic diversity, pathogenesis and prevention are re-evaluated and discussed.

Keywords: Lagos bat virus; lyssavirus; bats; rabies; Africa; South Africa

\section{Introduction}

Until the 1950s, it was thought that rabies virus (RABV) was the only causative agent of the disease known as rabies, but this changed when the first rabies-related virus, Lagos bat virus (LBV), was detected in 1956 in Nigeria [1]. With improvements in diagnostic techniques and molecular characterization technologies, the known lyssavirus species have significantly expanded [2], and 17 species are now recognized within the Lyssavirus genus (Table 1) [3]. Of these, at least seven have been reported from Africa [4]. These species are grouped into two phylogroups and several ungrouped viruses based on antigenic and phylogenetic properties, with LBV belonging to phylogroup II. The diversity described from Africa has led to the hypothesis that lyssaviruses may have originated from the African continent and subsequently co-evolved with their primary hosts, i.e., bats, for thousands of years $[5,6]$. We discuss the history of LBV detections, serological surveillance and new detections $(n=8)$ from passive surveillance in South Africa. The genetic diversity is re-evaluated, and the pathogenicity and implications for prevention and control are discussed.

Table 1. Lyssavirus classification, commonly associated hosts and geographical distribution.

\begin{tabular}{cccc}
\hline Lyssavirus Species & Phylogroup & $\begin{array}{c}\text { Geographical } \\
\text { Distribution }\end{array}$ & Host(s) $^{\mathbf{1}}$ \\
\hline Aravan lyssavirus & I & Eurasia & Myotis blythi \\
\hline Australian bat lyssavirus & I & Australasia & $\begin{array}{c}\text { Pteropus alecto } \\
\text { Saccolaimus flaviventris }\end{array}$ \\
\hline Bokeloh bat lyssavirus & I & Europe & Myotis nattereri \\
\hline Duvenhage lyssavirus & I & Africa & Nycteris thebaica \\
\hline European bat 1 lyssavirus & I & Europe & Eptesicus serotinus \\
\hline
\end{tabular}


Table 1. Cont.

\begin{tabular}{|c|c|c|c|}
\hline Lyssavirus Species & Phylogroup & $\begin{array}{l}\text { Geographical } \\
\text { Distribution }\end{array}$ & $\operatorname{Host}(s)^{1}$ \\
\hline European bat 2 lyssavirus & I & Europe & Myotis daubentonii \\
\hline Gannoruwa bat lyssavirus & I & Asia & Pteropus medius \\
\hline Ikoma lyssavirus & & Africa & Civettictis civetta $^{2}$ \\
\hline Irkut lyssavirus & $\mathrm{I}$ & Eurasia & Murina leucogaster \\
\hline Khujand lyssavirus & I & Eurasia & Myotis mystacinus \\
\hline Kotalathi bat lyssavirus ${ }^{3}$ & I & Europe & Myotis brandtii \\
\hline Lagos bat lyssavirus & II & Africa & $\begin{array}{c}\text { Eidolon helvum } \\
\text { Rousettus aegyptiacus } \\
\text { Epomophorus wahlbergi }\end{array}$ \\
\hline Lleida bat lyssavirus & & Europe & Miniopterus schreibersii \\
\hline Matlo bat lyssavirus ${ }^{4}$ & & Africa & Miniopterus natalensis \\
\hline Mokola lyssavirus & II & Africa & Felis catus $^{2}$ \\
\hline Rabies lyssavirus & I & $\begin{array}{c}\text { Almost } \\
\text { worldwide }\end{array}$ & Most mammalian species \\
\hline Shimoni bat lyssavirus & II & Africa & Macronycteris vittatus \\
\hline Taiwan bat lyssavirus & $\mathrm{I}$ & Asia & Pipistrellus abramus \\
\hline Nest Caucasian bat lyssaviru & & Eurasia & Miniopterus schreibersii \\
\hline
\end{tabular}

${ }^{1}$ Only the most frequently reported species are indicated; ${ }^{2}$ unknown reservoir host, listed species considered spillover hosts. ${ }^{3}$ Tentative species; ${ }^{4}$ potential novel species.

\section{Lagos Bat Virus Detections}

Surveillance efforts focused on encephalitic and tropical fevers isolated a virus from male Eidolon helvum bats in 1956 on Lagos Island in Nigeria via the mouse inoculation test. This virus, LBV, was not neutralized by any rabies immune sera, indicating that it was not a strain of RABV [1] and was initially classified as a potential arbovirus. In 1969, members of the Yale Arbovirus Research Unit, in collaboration with the Centers for Disease Control and Prevention, USA, were able to classify LBV as a rhabdovirus using electron microscopy and showed that LBV was serologically related to another lyssavirus, i.e., Mokola virus (MOKV) only identified in the 1970s [7,8]. During the period 1956-2020, only 32 LBV cases were laboratory confirmed using monoclonal antibody typing or sequencing (Figure 1).

\subsection{Detections in Eidolon helvum}

A total of four LBV detections have been reported. After the first detection in 1956, LBV was only detected in E. helvum again 29 years later in Senegal [9]. A pilot study was conducted in Kenya during the period 2006-2007 in the Global Disease Detection Program framework to detect emerging infectious agents in bats. During this period, 1221 bats representing at least 30 bat species were tested, and one LBV isolate was obtained from a dead E. helvum bat. Several organs were also positive for viral RNA, including the brain, salivary glands, tongue, bladder, lung, stomach, adrenal glands, liver, heart, ovaries and kidneys [10]. In 2013, a broad spectrum non-targeted virus isolation study was undertaken in Kumasi, Ghana, and LBV was isolated from an apparent healthy E. helvum bat [11]. 


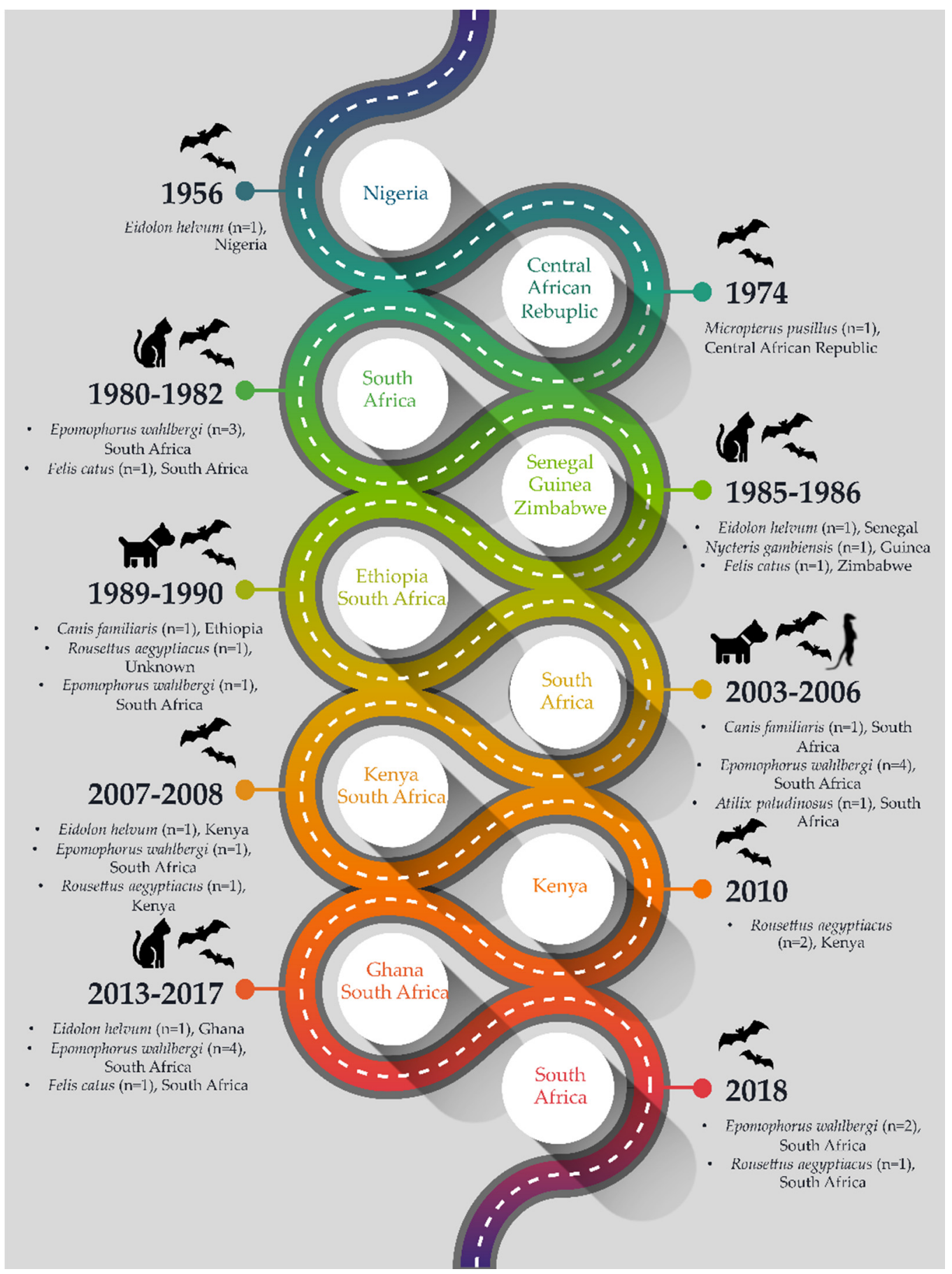

Figure 1. Timeline of laboratory confirmed Lagos bat virus detections.

\subsection{Detections in Epomophorus wahlbergi}

All LBV detections in Epomophorus wahlbergi have been restricted to the KwaZuluNatal (KZN) province in South Africa and were first detected in the early 1980s [12]. The province experienced an epidemic of canine rabies during this period, and heightened public awareness led to the submission of 282 bats noted for abnormal behaviour (fluttering on the ground) for rabies diagnosis. Ten bats submitted in 1980 and three in 1981 were positive for lyssavirus antigens with the fluorescent antibody test (FAT). Of these positive bats, only one was positively identified as E. wahlbergi, although it is believed that all individuals were of the same species. Of the 13 positive bats, only three were subsequently isolated and confirmed to be LBV with monoclonal antibody tests $[9,12,13]$. The next LBV 
case was reported in an E. wahlbergi bat found dead in 1990 [9]. LBV was only detected in E. wahlbergi again over a decade later in 2003 after implementing a passive surveillance study [14] during which four cases were identified [14,15]. In 2003, a dead E. wahlbergi was submitted for rabies testing after being caught by a domestic cat [14]. In 2004, a resident found a dead E. wahlbergi bat on her lawn one morning. She reported hearing squeaking noises around her house the previous evening. The FAT was positive for both bats with subsequent successful virus isolation, monoclonal antibody typing, RT-PCR and sequencing [14]. The following year (2005), the caretaker at a communal outdoor sports complex found an adult E. wahlbergi bat with her pup still attached on the lawn. The caretaker placed the bats in a nearby tree. However, they were later found on the ground again, where a cat was toying with them. The bats were then submitted to a local bat rehabilitator, though the adult bat had died. The FAT performed for the adult bat was negative; however, RT-PCR detected LBV RNA in the brain [14]. The pup had one apparent bite wound, presumably from the cat, but appeared to be healthy at submission to the bat rehabilitator and was feeding well, though it died four days later. Diagnostic tests (FAT and RT-PCR) on the pup's brain material were negative [14]. An E. wahlbergi bat was submitted for rabies diagnosis from a bat rehabilitator in 2006. The bat was initially very calm but appeared to be dehydrated and had trouble breathing. The bat was given water and liquidized fruit; although the bat drank the liquids, the bat rehabilitator noted that the throat was inflamed with severe swelling. After consumption of the liquids, the bat started producing excessive amounts of saliva and shaking its head. The eyes of the bat appeared to be opaque, and its breathing deteriorated. The bat eventually started choking and died shortly after. This bat's brain material was positive with FAT and identified as LBV with RTPCR and sequencing $[15,16]$. Shortly after that, in 2008, LBV was detected in a euthanized E. wahlbergi bat submitted for rabies diagnosis by a local veterinarian. The veterinarian initially treated the bat for hyperthermia; however, the veterinarian decided to euthanize the bat after it started to display neurological signs, including difficulty swallowing [17].

\subsection{Detections in Rousettus sp.}

In 1999, a bat imported from Africa (possibly Togo or Egypt) died in the department du Gard, France, and was shown to be infected with LBV. The bat species involved was initially reported as Pteropus sp. but was later corrected to more likely be Rousettus sp. [18,19]. During the period 2008-2011, LBV was detected three times in Rousettus aegyptiacus in Kenya [20,21]. All three bats were found dead at different locations in Kenya, with nearly all tissues tested containing viral RNA. In addition, the virus could be isolated from a single faecal swab, and a significantly high viral titre of $10^{7.5} \mathrm{MICLD}_{50}$ (i.e., the median lethal dose for mice inoculated by the intracerebral route) was detected in a salivary gland [20,22].

\subsection{Detection in Micropterus pusillus}

The first and only detection of LBV in Micropterus pusillus (current taxonomic status: Epomophorus pusillus [23]) occurred in 1974 from Bozo, Central African Republic. The virus was detected in the brain, heart and spleen [24]. It was indicated that, serologically, this isolate could be distinguished from the original LBV isolate from Nigeria, and that cross-reactions with MOKV antibodies occurred [25].

\subsection{Detection in Nycteris gambianus}

Lagos bat virus was detected for the first and only time in an insectivorous bat (Nycteris gambianus) during a survey in 1985 in Guinea [9].

\subsection{Detections in Spillover Hosts}

The first report of LBV in a spillover host (an individual that comes into contact with the reservoir and is infected [26]) was in 1982 from a domestic cat in South Africa (KZN province). The cat was behaving abnormally and was previously vaccinated [9,27]. Another vaccinated domestic cat tested positive for LBV in Zimbabwe in 1986 [28]. The cat 
from the mining village of Dorowa was submitted for routine rabies diagnosis in Harare. The female cat was euthanized after a three-day illness characterized by incontinence, hypersensitivity, posterior paresis, convulsions, excessive salivation and aggression when handled. The cat had been vaccinated against rabies with Rabisin ${ }^{\circledR}$ three times, at three years, fifteen months and three months, prior to its LBV infection [28]. During routine rabies diagnosis performed at the National Research Institute of Health in Addis Ababa, Ethiopia, during the period 1989-1990, LBV was isolated from a domestic dog displaying rabies symptoms [29]. In 2003, LBV was detected in an Australian cattle dog that attacked people on a beach (Richards Bay, KZN). The dog was vaccinated against rabies; however, the owner was unsure of the vaccination date [15]. The first identification of LBV from a terrestrial wildlife species occurred in 2004 from a water mongoose (Atilax palidinosus) [30]. The animal was captured by the Society for the Prevention of Cruelty to Animals from a marshy valley in a residential area near Durban (KZN province, RSA). The animal appeared disorientated, attacked inanimate objects and alternated between friendly and aggressive behaviour.

\section{New Lagos Bat Virus Cases Identified in South Africa, 2013-2018}

Through passive surveillance networks, which include national diagnostic laboratories, bat rehabilitation centres, and bat interest groups, eight new cases of LBV have been identified in South Africa since 2013. Except for one case in R. aegyptiacus, all cases occurred in the KZN province of South Africa.

A large male E. wahlbergi bat was found grounded at a private residence in Scottburgh by children in 2013. They first thought that the bat was dead, but they provided the bat with water after discovering that it was alive. It was noted that the bat behaved abnormally. A local bat rehabilitator collected the bat, and it was observed that the bat was listless and had lost the use of its back legs. The bat's condition deteriorated (clinical signs included fever, anorexia, opaque eyes and paralysis), but it continued to drink water. The bat died shortly after that. The brain material tested positive with FAT and quantitative real-time reverse-transcriptase polymerase chain reaction (qRT-PCR) [31] (laboratory identification number: UP2250).

During a small retrospective study performed to molecularly characterize FAT-positive samples from cats in KZN [32], LBV was detected (coordinates: -30.218130, 30.790770). In October 2013, the cat's owner received bites from the animal when it was approached and subsequently took the cat to a local veterinarian. The veterinarian placed the animal in quarantine and observed clinical signs consistent with rabies, including aggression, anorexia and ataxia. The cat eventually lost all motor control and died approximately two weeks later. Brain material was submitted for rabies diagnosis and tested positive with FAT and qRT-PCR [31] (Allerton Provincial Veterinary Laboratory identification number: 13/599). Due to the bite sustained by the owner, post-exposure prophylaxis was initiated [33].

In January 2014, a juvenile E. wahlbergi was submitted to a veterinarian by a resident (coordinates: $-29.812870,30.862760$ ). The veterinarian and a veterinary nurse at the clinic cared for the bat for approximately two weeks before it suddenly died. During this time, the bat appeared healthy, with no clinical signs of illness. The veterinary nurse was also bitten on the finger by the bat, and as such, post-exposure prophylaxis was initiated. The bat carcass was submitted for rabies diagnosis, and brain material tested positive with FAT and qRT-PCR [31] (Allerton Provincial Veterinary Laboratory identification number: 14/070). Several other organs were also positive for viral RNA with qRT-PCR, including the heart $\left(1.76 \times 10^{4}\right.$ RNA copies $)$, intestine $\left(1.62 \times 10^{4}\right.$ RNA copies $)$ and the salivary glands (5.62 $\times 10^{3}$ RNA copies) [33].

In April 2016, an adult male E. wahlbergi bat was found on a path (under palm trees, next to an electric fence) by children in Umhlanga. The bat was submitted to a local veterinarian and appeared to be healthy. However, due to the human exposures involved, post-exposure prophylaxis was initiated, and the bat was euthanized and submitted for 
rabies diagnosis. The brain material tested positive with FAT and qRT-PCR [31] (laboratory identification number: UP6414).

During the same time, another male E. wahlbergi bat was found in the Botanic Gardens (coordinates: $-29.607437,30.341093$ ). The bat was submitted to a local bat rehabilitator that noted a pneumonia-like disease. The bat died approximately one month later and tested positive with FAT and qRT-PCR [31] (laboratory reference number: UP7398).

In March 2018, an adult female E. wahlbergi bat was submitted by a local veterinarian for rabies testing (coordinates: $-30.084770,30.865550$ ). The reported clinical signs included profuse salivation, panting, general weakness, teeth grinding and the inability to open its eyes. The brain material tested positive for viral RNA with qRT-PCR [34] (laboratory reference number: UP8873).

A month later, a homeowner reported two fruit bats falling out of a tree on his property (coordinates: $-30.08430,30.86557$ ). His two dogs attempted to retrieve the bats, during which one of the dogs received a bite from one of the bats. Both bats were submitted for rabies testing. One of these bats tested positive for viral RNA with qRT-PCR [34] (laboratory reference number: UP9878; Allerton Provincial Laboratory reference number: 18/495).

During the same time, an adult female R. aegyptiacus bat was found dead at Matlapitsi cave, GaMafefe, Limpopo province (coordinates: $-24.11487,30.12151$ ), when sampled as part of a broader biosurveillance program on viruses. The brain material tested positive for viral RNA with qRT-PCR [34] (laboratory reference number: UP8931).

\section{Surveillance for Lagos Bat Virus}

Rabies is recognized as an underreported disease with a diverse group of viral species as causative agents. Africa is host to diverse lyssaviruses, with surveillance for RABV already poor and even more so for rabies-related lyssaviruses [2,6]. Diagnostic methods, such as the fluorescent antibody test (FAT), where available, cannot distinguish between different lyssaviruses, resulting mostly in the reporting of rabies-positive samples in general with no further characterization of the causative agent [32]. Active surveillance (i.e., the monitoring of bat populations for the presence of lyssaviruses) in wildlife and specifically bats is lacking, also complicated by the neurological pathway of the disease. After infection, the virus enters the neuronal system where it is protected from the immune system, and then moves slowly towards the brain, where it replicates in high titre. Only after this does the virus disseminate to other organs, including intermittent viral shedding in saliva. Lyssaviruses are non-viraemic (absent in the blood) and not excreted in urine or faecal material. Therefore, brain material is the most reliable sample for virus detection, and positive detection is associated with clinical signs. Bats are considered the primary hosts for lyssaviruses [5,6], with 13 extant families and an estimated 58 genera and 339 species reported in Africa [23,35], representing more than $20 \%$ of global bat diversity. Very few studies on lyssavirus surveillance for nucleic acid detection in Africa (Table S1) have been published. Subsequently, very few bat genera have been investigated sufficiently (Table 2) compared with species naturally infected with LBV. However, surveillance for lyssaviruses in healthy bat populations using destructive sampling methodologies (since brain material is tested, bats need to be humanely sacrificed) is not very efficient for detecting infections [22]. Over 5000 individual bats have been tested in Africa with a detection rate of less than 1\% (Table 2). Bat species known to be reservoirs for lyssaviruses have been disproportionately tested (Figure 2), such as E. helvum and R. aegyptiacus, compared to other bat species occurring in Africa. Therefore, conclusions regarding the host range, distribution, spillover incidence and spillover hosts of LBV are tentative. 
Table 2. Summary of bat families and genera tested during surveillance for lyssavirus nucleic acid in Africa (details of studies can be found in Table S1).

\begin{tabular}{|c|c|c|c|c|c|c|}
\hline Host Family & Genera & Species ${ }^{1}$ & $\begin{array}{l}\text { Genera (Tested } \\
\text { Species }{ }^{2} \text { ) }\end{array}$ & $\begin{array}{c}\text { Tested } \\
\text { Individuals }\end{array}$ & $\begin{array}{c}\text { Positive } \\
\text { Individuals }\end{array}$ & Virus \\
\hline PTEROPODIDAE & 13 & 44 & $5(8)$ & 2350 & 4 & Lagos bat virus \\
\hline HIPPOSIDERIDAE & 4 & 21 & $2(3)$ & 62 & 1 & Shimoni bat virus \\
\hline MEGADERMATIDAE & 2 & 2 & $2(2)$ & 29 & 0 & \\
\hline RHINOLOPHIDAE & 1 & 38 & $1(11)$ & 321 & 0 & \\
\hline RHINONYCTERIDAE & 3 & 6 & $2(2)$ & 21 & 0 & \\
\hline RHINOPOMATIDAE & 1 & 3 & $1(1)$ & 4 & 0 & \\
\hline MYZOPODIDAE & 1 & 2 & $0(0)$ & 0 & 0 & \\
\hline EMBALLONURIDAE & 4 & 12 & $2(3)$ & 44 & 0 & \\
\hline NYCTERIDAE & 1 & 15 & $1(3)$ & 69 & 1 & Duvenhage virus \\
\hline MOLOSSIDAE & 7 & 44 & $4(7)$ & 333 & 0 & \\
\hline CISTUGONIDAE & 1 & 2 & $0(0)$ & 0 & 0 & \\
\hline MINIOPTERIDAE & 1 & 26 & $1(5)$ & 555 & 2 & Matlo bat lyssavirus \\
\hline VESPERTILIONIDAE & 19 & 124 & $11(19)$ & 303 & 0 & \\
\hline Not determined & - & - & - & 1193 & 0 & \\
\hline TOTALS & 58 & 339 & $32(64)$ & 5284 & 8 & $0.15 \%$ \\
\hline
\end{tabular}

${ }^{1}$ Total species counts are fluid due to ongoing species rearrangement or reassignment; ${ }^{2}$ not all bats sampled are identified at species level.

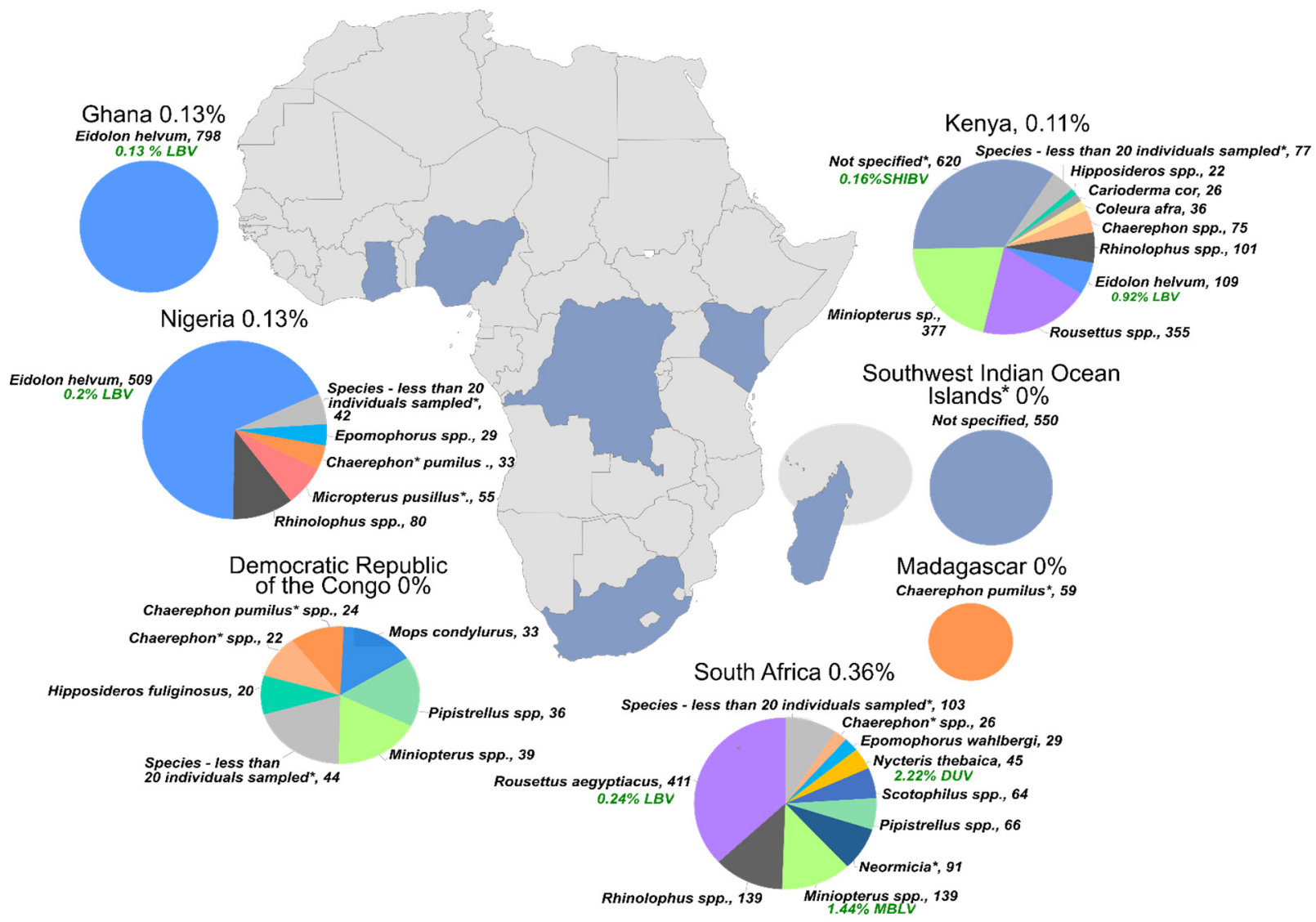

Figure 2. The number of bats surveyed for lyssavirus RNA during active nucleic acid surveillance activities depicted as pie charts. The countries in Africa where the surveillance was conducted are indicated in blue on the map-Ghana, Nigeria, Democratic Republic of Congo, South Africa, Kenya, Madagascar and the South Indian Ocean Islands (circled in grey). The numbers next to species names indicate individuals tested. Species with an asterisk indicate a referral to Table S1 for further details regarding taxonomic changes. All species for whom less than 20 individuals were tested are grouped together for visual simplicity with additional details in Table S1. 
Another approach to investigating lyssaviruses is to conduct serological surveillance. Antibodies may only develop very late in the disease. In particular, bats seem to develop high antibody titres without developing disease, probably due to abortive infection. Therefore, high seroprevalence has been described to be associated with the absence of virus. Serological surveillance usually utilizes non-destructive sampling, i.e., bats are caught, blood is collected and bats are released. For lyssaviruses, the rapid fluorescent focus inhibition test (RFFIT) and the fluorescent antibody virus neutralization test (FAVN) are most frequently used [22,36]. Both methods are based on testing dilutions of sera against a constant challenge virus dose in vitro to quantify virus neutralizing antibodies (VNAs). The presence of VNAs implies previous exposure to the antigen used in the test [37] and is not indicative of an active infection. Like surveillance for nucleic acids, serological surveillance for lyssaviruses has been limited to only a few countries, with members of the Pteropodidae family being disproportionately tested (Table S2 and Table 3). The presence of VNAs has been detected in over $25 \%$ of the bats sampled (Table S2, Figure 3), significantly higher than nucleic acid detection rates.

Table 3. Summary of bat families and genera tested during surveillance for Lagos bat virus neutralizing antibodies in Africa (details of studies can be found in Table S2).

\begin{tabular}{|c|c|c|c|c|c|c|}
\hline Host Family & Genera & Species ${ }^{1}$ & $\begin{array}{c}\text { Genera } \\
\left(\text { Tested Species }{ }^{2}\right)\end{array}$ & $\begin{array}{c}\text { Tested } \\
\text { Individuals }\end{array}$ & $\begin{array}{c}\text { Positive } \\
\text { Individuals }\end{array}$ & $\begin{array}{l}\text { Percentage } \\
\text { Positive }\end{array}$ \\
\hline PTEROPODIDAE & 13 & 44 & $8(14)$ & 3064 & 1048 & 34.2 \\
\hline HIPPOSIDERIDAE & 4 & 21 & $2(3)$ & 148 & 5 & 3.4 \\
\hline MEGADERMATIDAE & 2 & 2 & $1(1)$ & 3 & 0 & 0 \\
\hline RHINOLOPHIDAE & 1 & 38 & $1(1)$ & 44 & 0 & 0 \\
\hline RHINONYCTERIDAE & 3 & 6 & $1(2)$ & 19 & 2 & 17.8 \\
\hline RHINOPOMATIDAE & 1 & 3 & $0(0)$ & 0 & 0 & 0 \\
\hline MYZOPODIDAE & 1 & 2 & $0(0)$ & 0 & 0 & 0 \\
\hline EMBALLONURIDAE & 4 & 12 & $1(1)$ & 24 & 0 & 0 \\
\hline NYCTERIDAE & 1 & 15 & $1(1)$ & 14 & 0 & 0 \\
\hline MOLOSSIDAE & 7 & 44 & $3(13)$ & 517 & 20 & 3.9 \\
\hline CISTUGONIDAE & 1 & 2 & $0(0)$ & 0 & 0 & 0 \\
\hline MINIOPTERIDAE & 1 & 26 & $1(5)$ & 343 & 4 & 1.2 \\
\hline VESPERTILIONIDAE & 19 & 124 & $8(8)$ & 120 & 4 & 3.3 \\
\hline TOTALS & 58 & 339 & $27(49)$ & 4296 & 1083 & 25.2 \\
\hline
\end{tabular}

${ }^{1}$ Total species counts are fluid due to ongoing species rearrangement or reassignment; ${ }^{2}$ not all bats sampled are identified at species level.

However, the interpretation of serological results is significantly influenced by the cross-reactivity of antibodies to different lyssavirus species and the cut-off thresholds used in the assay [37]. For lyssaviruses, cross-reactivity has been described for viruses belonging to the same phylogroup, such as European bat lyssavirus 1 and Duvenhage virus [38], and for MOKV and LBV $[8,10,39]$. An attempt to quantify this level of cross-reactivity indicated that only $67 \%$ of the antigenic variation was predictable from sequencing information [40]. The interpretation of serological cross-reactivity is further complicated by variable individual responses to exposure with reports that very high antibody titres may enable the neutralization of divergent viruses [41]. Another consideration is the choice of challenge virus used in the test, as cross-reaction was not observed between some LBV isolates. Sera from E. helvum in Ghana could neutralize a lineage A virus (isolate 31,225, E. helvum, Ghana, 2013) but could not neutralize a lineage B virus (E. helvum, Nigeria, 1956) [11].

The antibody prevalence in a specific population is determined by comparing the results obtained to a reference cut-off value [37]. Therefore, the cut-off value would determine if a given sample is positive or negative for antibodies. Studies have reported using different cut-off values in addition to using different assays. Considering the variation that can occur within assays and between assays and laboratories with the lack of an international reference standard for rabies-related viruses, it becomes difficult to compare seroprevalence studies directly. For example, cut-off values used for LBV seroprevalence 
studies ranged from 1:9 [42] up to 1:40 [43]. This variation in cut-off values directly impacts the assay sensitivity and specificity [37] and, therefore, has a significant effect on data interpretation and ultimately the estimated antibody prevalence. Although serological surveillance is informative, it should be interpreted with caution due to the inherent limitations.
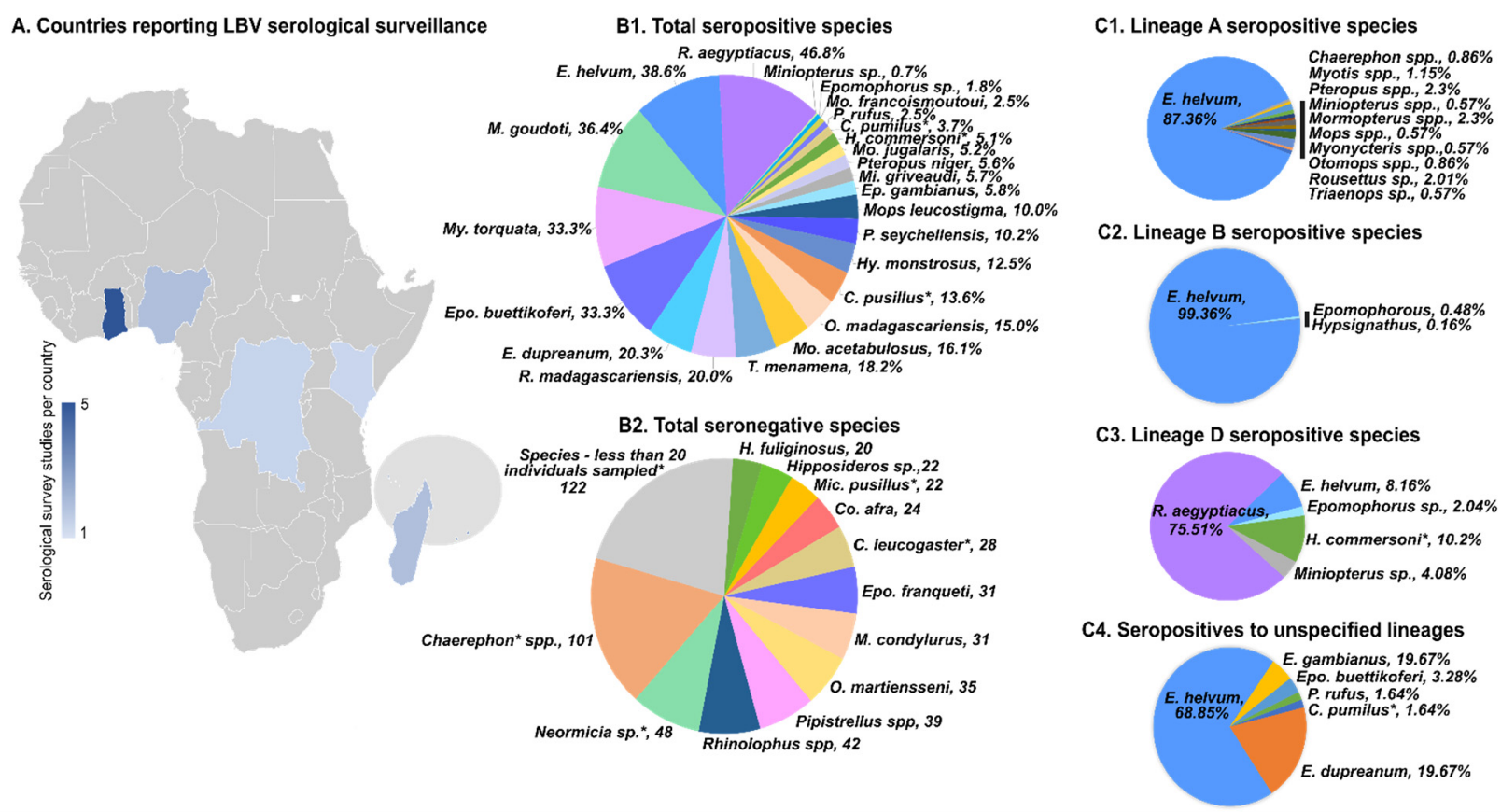

Figure 3. Map depicts the countries where Lagos bat virus serological studies have been reported from bat species, indicated according to the number of studies per country (Ghana, Nigeria, Democratic Republic of Congo, Kenya, Madagascar and Southwestern Indian Islands). Southwestern Indian Ocean islands include Anjouan, La Réunion, Mahé, Mayotte and Mauritius. (B1) Bat species from all studies that were seropositive, indicated as percentage positive per species. (B2) Bat species from all studies that were seronegative, indicated as number of bats tested per species. Bat species with seropositivity to LBV lineage A (C1), lineage B (C2), lineage D (C3) and unspecified lineages (C4) are also indicated as a percentage of the total individuals seropositive for each respective lineage. Table S2 provides more details of taxonomic changes for species indicated with an asterisk and specific sample numbers.

\section{Lagos Bat Virus Diversity}

With the description of several viruses related to RABV during the mid-twentieth century, the Lyssavirus genus was initially divided into four serotypes, i.e., RABV (serogroup 1), LBV (serogroup 2), MOKV (serogroup 3) and DUVV (serogroup 4), based on reaction patterns with monoclonal antibodies [44]. Additional isolations of lyssaviruses followed and, together with improvements in molecular techniques for genetic characterization, led to the description of lyssavirus genotypes that followed the serogroup designation with an additional two genotypes [45]. During the 1990s, it was suggested that lyssavirus genotypes are divided based on a threshold nucleotide identity of $80 \%$ and $93 \%$ for amino acids $[45,46]$. The first comprehensive phylogenetic studies of LBV indicated that these viruses could be divided into three distinct lineages, i.e., lineage A-C. Viruses belonging to lineage A were also shown to exceed the genotype threshold compared to lineages B and C, suggesting that lineage A should constitute a new genotype [16,47]. It was also during this time that the ICTV approved the classification of lyssaviruses into species. This complex taxonomic entity would, therefore, consider several characteristics and not rely solely on genetic distance. Although LBV isolates exceed current genetic species demarcation criteria, it is not regarded as separate species [3]. An additional lineage D was also described from Kenya and more recently from South Africa (this report) with R. aegyptiacus as the only 
known associated host (Figure 4). The first full genome for LBV was only published in 2008, and currently, there are seven full genomes available with the first and only lineage C LBV genome (this report) available for comparison. The genetic identity for complete concatenated genomes ranged from $76 \%$ to $98.8 \%$ for nucleotides and $87.8 \%$ to $99.7 \%$ for amino acids (Table 4). It appears that LBV displays genetic spatiotemporal stability. For lineage A viruses, the only lineage with multiple full genomes available, that were detected 28 years apart from West and East Africa, less than 1.5\% nucleotide divergence is observed. This suggests that the viruses of each lineage are adapted to specific hosts [10]. Due to limited surveillance in Africa, no conclusive assumptions can be made regarding the host range of LBV; however, available data suggest that lineage A and $B$ viruses are associated with $E$. helvum, lineage $\mathrm{C}$ with $E$. wahlbergi and lineage $\mathrm{D}$ with $R$. aegytiacus.

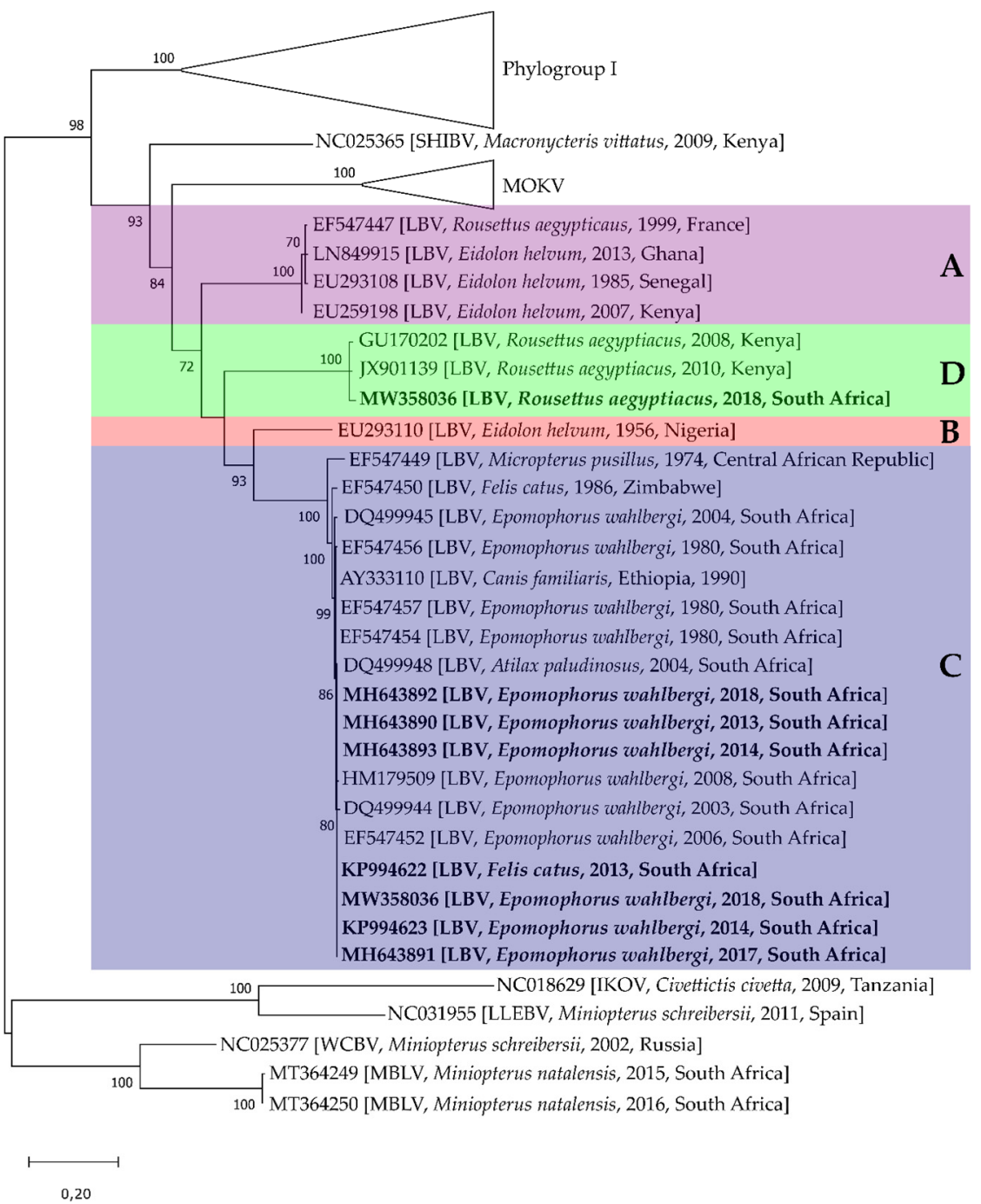

Figure 4. Maximum likelihood phylogenetic tree of the complete nucleoprotein gene of available Lagos bat virus sequences and representatives of all lyssavirus species (Table S3) using the general time reversible model with gamma distribution and invariant sites $(\mathrm{GTR}+\mathrm{G}+\mathrm{I})$. Lagos bat virus lineages (A-D) are indicated in capital letters. The reliability of the branching pattern was statistically evaluated by bootstrap analysis of 1000 replications and are indicated the nodes. Scale bar indicates the number of substitutions per site. Sequences generated in this report are indicated in bold. 
Table 4. Nucleotide (grey) and amino acid identity of concatenated Lagos bat virus genomes.

\begin{tabular}{cccccccc}
\hline & & Lineage A & & Lineage B & Lineage C & \multicolumn{2}{c}{ Lineage D } \\
\hline & LN849915 $^{\mathbf{1}}$ & NC020807 $^{\mathbf{2}}$ & EU259198 $^{\mathbf{3}}$ & EU293110 $^{\mathbf{4}}$ & MH643893 $^{\mathbf{5}}$ & GU170202 $^{\mathbf{6}}$ & JX901139 $^{\mathbf{7}}$ \\
\hline LN849915 & & 98.7 & 98.8 & 76.3 & 76 & 76.3 & 76.4 \\
\hline NC020807 & 99.7 & & 98.8 & 76.2 & 76 & 76.2 & 76.4 \\
\hline EU259198 & 99.6 & 99.6 & & 76.2 & 76 & 76.3 & 76.7 \\
\hline EU293110 & 87.9 & 87.9 & 87.8 & & 79.6 & 77.1 \\
\hline MH643893 & 88.9 & 88.9 & 88.8 & 92.2 & & 77.2 \\
\hline GU170202 & 89.5 & 89.6 & 89.5 & 88.4 & 89.2 & & 98.3 \\
\hline JX901139 & 89.5 & 89.6 & 89.5 & 88.3 & 89.3 & 99.4 \\
\hline
\end{tabular}

${ }^{1}$ E. helvum, 2013, Ghana; ${ }^{2}$ E. helvum, 1985, Senegal; ${ }^{3}$ E. helvum, 2007, Kenya; ${ }^{4}$ E. helvum, 1956, Nigeria; ${ }^{5}$ E. wahlbergi, 2014, South Africa; ${ }^{6}$

R. aegyptiacus, 2008, Kenya; ${ }^{7}$ R. aegyptiacus, 2010, Kenya.

\section{Pathogenesis}

Since LBV was shown to be serologically related to RABV [8], the question arose on whether pathogenicity, disease development and pathological findings are comparable. The first study investigating the pathogenicity (i.e., the ability to cause disease) of LBV was performed in monkeys and dogs [48]. Results indicated that similar to RABV, a preference for the central nervous system was observed. However, reduced pathogenicity was observed when these animals were infected via the intramuscular route (IM). Several decades after this, a comparative study investigating the differences in pathogenicity, immunogenicity and genetics of lyssaviruses was performed [39]. Results indicated that phylogroup II viruses (i.e., LBV and MOKV) were not pathogenic via the IM route. This was due to an amino acid substitution in the glycoprotein gene (Arginine at position 333). Considering the increased genetic diversity described for LBV, the decreased peripheral pathogenicity was revisited in subsequent investigations with results indicating the equal, and in some cases, increased pathogenicity of LBV compared to RABV [17,49]. These studies indicated that a lyssavirus species' pathogenicity should not be based on a single isolate and that a single amino acid change cannot predict pathogenicity. Several domains considered to be important for pathogenicity are conserved in LBV isolates; however, several other mutations also occur that reportedly result in reduced pathogenicity (Table 5). Based on genetic data and experimental infections in mice, it would appear that there is some cooperativity between pathogenic domains within LBV but that currently unknown additional domains or factors exist that contribute to the pathogenicity of lyssaviruses [17].

Table 5. Conservation of amino acids ${ }^{1}$ of pathogenic domains on Lagos bat virus genomes.

\begin{tabular}{|c|c|c|c|c|c|c|c|c|c|}
\hline \multirow{2}{*}{ Protein $^{2}$} & \multirow{2}{*}{ Region } & \multirow{2}{*}{$\operatorname{Ref}^{3}$} & \multicolumn{3}{|c|}{ Lineage A } & \multirow{2}{*}{$\begin{array}{c}\text { Lineage B } \\
\text { EU } \\
293110\end{array}$} & \multirow{2}{*}{$\begin{array}{c}\text { Lineage C } \\
\mathrm{MH} \\
643893\end{array}$} & \multicolumn{2}{|c|}{ Lineage D } \\
\hline & & & $\begin{array}{c}\text { EU } \\
259198\end{array}$ & $\begin{array}{c}\text { NC } \\
020807\end{array}$ & $\begin{array}{c}\text { LN } \\
849915\end{array}$ & & & $\underset{901139}{J X}$ & $\begin{array}{c}\text { GU } \\
170202\end{array}$ \\
\hline \multirow{2}{*}{$\mathrm{N}$} & 273 & \multirow{2}{*}{ [50] } & F & F & F & $\mathrm{F}$ & $\mathrm{F}$ & $\mathrm{F}$ & F \\
\hline & 394 & & F & F & F & F & F & F & $\mathrm{F}$ \\
\hline $\mathrm{P}$ & 144-148 & [51] & RQTQT & RQTQT & RQTQT & KQTQT & KQTQT & KNTQT & KNTQT \\
\hline \multirow{5}{*}{ M } & $22-25$ & [52] & ASAP & ASAP & ASAP & PSAP & PSAP & ASAP & ASAP \\
\hline & $35-38$ & [53] & PPEY & PPEY & PPEY & PPEY & PPEY & PPEY & PPEY \\
\hline & 77 & \multirow{2}{*}{ [54] } & $\mathrm{K}$ & K & K & K & K & K & K \\
\hline & 81 & & $\mathrm{~N}$ & $\mathrm{~N}$ & $\mathrm{~N}$ & $\mathrm{~N}$ & $S$ & $\mathrm{~N}$ & $\mathrm{~N}$ \\
\hline & 95 & [55] & I & I & I & $\mathrm{M}$ & $\mathrm{V}$ & I & I \\
\hline
\end{tabular}


Table 5. Cont.

\begin{tabular}{|c|c|c|c|c|c|c|c|c|c|}
\hline \multirow[b]{2}{*}{ Protein $^{2}$} & \multirow{2}{*}{ Region } & \multirow[b]{2}{*}{$\operatorname{Ref}^{3}$} & \multicolumn{3}{|c|}{ Lineage A } & \multirow{2}{*}{$\begin{array}{c}\text { Lineage B } \\
\text { EU } \\
293110\end{array}$} & \multirow{2}{*}{$\begin{array}{c}\text { Lineage C } \\
\mathrm{MH} \\
643893\end{array}$} & \multicolumn{2}{|c|}{ Lineage D } \\
\hline & & & $\begin{array}{c}\text { EU } \\
259198\end{array}$ & $\begin{array}{c}\text { NC } \\
020807\end{array}$ & $\begin{array}{c}\text { LN } \\
849915\end{array}$ & & & $\underset{901139}{J X}$ & $\begin{array}{c}\text { GU } \\
170202\end{array}$ \\
\hline \multirow{9}{*}{ G } & 132 & [56] & $\mathrm{L}$ & $\mathrm{L}$ & $\mathrm{L}$ & $\mathrm{L}$ & $\mathrm{L}$ & $\mathrm{L}$ & $\mathrm{L}$ \\
\hline & 194 & [57] & $\mathrm{T}$ & $\mathrm{T}$ & $\mathrm{T}$ & $\mathrm{T}$ & $\mathrm{T}$ & $\mathrm{T}$ & $\mathrm{T}$ \\
\hline & 198 & [56] & $\mathrm{R}$ & $\mathrm{R}$ & $\mathrm{R}$ & K & $\mathrm{K}$ & $\mathrm{R}$ & $\mathrm{R}$ \\
\hline & 242 & \multirow{3}{*}{ [58] } & $S$ & $S$ & $S$ & $S$ & $S$ & $S$ & $S$ \\
\hline & 255 & & $\mathrm{D}$ & $\mathrm{D}$ & $\mathrm{D}$ & $\mathrm{N}$ & $\mathrm{N}$ & $\mathrm{N}$ & $\mathrm{N}$ \\
\hline & 268 & & I & I & I & V & I & $\mathrm{L}$ & $\mathrm{L}$ \\
\hline & 318 & \multirow{2}{*}{ [59] } & $\mathrm{L}$ & $\mathrm{L}$ & $\mathrm{L}$ & $\mathrm{L}$ & I & $\mathrm{L}$ & $\mathrm{L}$ \\
\hline & 352 & & $\mathrm{M}$ & $\mathrm{M}$ & M & V & $\mathrm{V}$ & $\mathrm{L}$ & $\mathrm{L}$ \\
\hline & $330-333$ & [60-62] & KRVD & KRVD & KRVD & LKVD & LRVD & RRVD & RRVD \\
\hline
\end{tabular}

${ }^{1}$ Amino acid abbreviations. A: Alanine; E: Glutamic acid; F: Phenylalanine; I: Isoleucine; K: Lysine; L: Leucine; M: Methionine; N: Asparagine; P: Proline; Q: Glutamine; R: Arginine; S: Serine; T: Threonine; V: Valine; Y: Tyrosine; ${ }^{2}$ Gene abbreviations. N: nucleoprotein gene; P: phosphoprotein gene; M: matrix protein gene; G: glycoprotein gene; ${ }^{3}$ reference for the description and the influence of the mutation.

Experimental infections (Table 6) have mostly been performed in non-reservoir hosts, such as mice, potentially resulting in inaccurate disease progression assumptions in naturally infected animals. More recently, the pathogenesis of LBV in one of its natural hosts, i.e., E. helvum, was investigated [63,64]. Similar mortality rates, as observed in other animals, were reported (Table 6). Clinical signs observed in experimentally infected bats appear similar to animals naturally infected with LBV (Figure 5). Additionally, lyssavirus antigens were detected in tongue epithelium and, together with the salivary glands, are probable virus excretion sites $[63,64]$. However, it was noted that for four bats, experimentally infected with different LBV doses $\left(10^{0.1}-10^{4.1} \mathrm{TCID}_{50}\right)$, no clinical signs were observed before the bats were found dead [63]. This phenomenon has also been reported in bats naturally infected with LBV and warrants further investigation $[1,11]$.

The mechanisms of virus maintenance and transmission of lyssaviruses in bats are not well understood and could be influenced by various factors $[2,26]$. The experimental infection of E. helvum with LBV indicated that bats that survived the challenge had developed virus neutralizing antibodies (53\%), suggesting that bats can develop an immune response without clinical disease development and thus not excrete virus [63]. This would support surveillance results, indicating high seroprevalence and low virus detection in Africa.

Table 6. Experimental infections of animals with Lagos bat virus.

\begin{tabular}{|c|c|c|c|c|c|c|}
\hline Host & Route1 & Dose & Isolate & Clinical Signs & Mortality & Reference \\
\hline \multirow{2}{*}{ Macaca mulatta } & IC & \multirow{4}{*}{$\begin{array}{c}6.2 \log \\
\mathrm{ICDL}_{50} / \mathrm{mL}\end{array}$} & \multirow{4}{*}{$\begin{array}{c}\text { 8619NGA } \\
\text { (EU293110) }\end{array}$} & Agitation & $100 \%(n=2)$ & \multirow{4}{*}[48]{} \\
\hline & IM & & & Paresis & $20 \%(n=5)$ & \\
\hline \multirow{2}{*}{ Canine } & IC & & & Depression, incoordination & $100 \%(n=2)$ & \\
\hline & IM & & & No clinical signs & $0 \%(n=2)$ & \\
\hline $\begin{array}{c}\text { Mice } \\
\text { (BALB } / 3 \mathrm{H})\end{array}$ & $\mathrm{IM}$ & $3 \times 10^{5} \mathrm{LD}_{50}$ & $\begin{array}{c}\text { 8619NGA } \\
\text { (EU293110) }\end{array}$ & $\mathrm{N} / \mathrm{A}$ & $0 \%$ & [39] \\
\hline
\end{tabular}


Table 6. Cont.

\begin{tabular}{|c|c|c|c|c|c|c|}
\hline Host & Route1 & Dose & Isolate & Clinical Signs & Mortality & Reference \\
\hline \multirow{24}{*}{ Mice (ICR) } & IC & $10^{2} \mathrm{MICLD}_{50}$ & \multirow{3}{*}{$\begin{array}{l}\text { 0406SEN } \\
\text { (EU93108) }\end{array}$} & \multirow{24}{*}{ Not specified } & $100 \%(n=5)$ & \multirow{24}{*}{ [49] } \\
\hline & $\mathrm{IM}$ & $10^{3} \mathrm{MICLD}_{50}$ & & & $60 \%(n=5)$ & \\
\hline & $\mathrm{IM}$ & $10^{6} \mathrm{MICLD}_{50}$ & & & $100 \%(n=5)$ & \\
\hline & IC & $10^{2} \mathrm{MICLD}_{50}$ & \multirow{3}{*}{$\begin{array}{c}\text { Afr1999 } \\
\text { (EF547447) }\end{array}$} & & $100 \%(n=5)$ & \\
\hline & $\mathrm{IM}$ & $10^{3} \mathrm{MICLD}_{50}$ & & & $20 \%(n=5)$ & \\
\hline & IM & $10^{6} \mathrm{MICLD}_{50}$ & & & $100 \%(n=5)$ & \\
\hline & IC & $10^{2} \mathrm{MICLD}_{50}$ & \multirow{3}{*}{$\begin{array}{c}\text { Zim1986 } \\
(\text { EF547450) }\end{array}$} & & $100 \%(n=5)$ & \\
\hline & IM & $10^{3} \mathrm{MICLD}_{50}$ & & & $20 \%(n=5)$ & \\
\hline & $\mathrm{IM}$ & $10^{6} \mathrm{MICLD}_{50}$ & & & $20 \%(n=5)$ & \\
\hline & $\mathrm{IM}$ & $10^{2} \mathrm{MICLD}_{50}$ & \multirow{3}{*}{$\begin{array}{c}\text { CAR1974 } \\
(\text { EF547449) }\end{array}$} & & $100 \%(n=5)$ & \\
\hline & $\mathrm{IM}$ & $10^{3} \mathrm{MICLD}_{50}$ & & & $0 \%(n=5)$ & \\
\hline & IM & $10^{6} \mathrm{MICLD}_{50}$ & & & $20 \%(n=5)$ & \\
\hline & IC & $10^{2} \mathrm{MICLD}_{50}$ & \multirow{3}{*}{$\begin{array}{l}\text { Mong2004 } \\
\text { (DQ499948) }\end{array}$} & & $100 \%(n=5)$ & \\
\hline & IM & $10^{3} \mathrm{MICDL}_{50}$ & & & $20 \%(n=5)$ & \\
\hline & $\mathrm{IM}$ & $10^{6} \mathrm{MICLD}_{50}$ & & & $20 \%(n=5)$ & \\
\hline & IC & $10^{2} \mathrm{MICLD}_{50}$ & \multirow{3}{*}{$\begin{array}{c}\text { SA2004 } \\
(\text { EF547458) }\end{array}$} & & $100 \%(n=5)$ & \\
\hline & IM & $10^{3} \mathrm{MICLD}_{50}$ & & & $40 \%(n=5)$ & \\
\hline & IM & $10^{6} \mathrm{MICLD}_{50}$ & & & $60 \%(n=5)$ & \\
\hline & IC & $10^{2} \mathrm{MICLD}_{50}$ & \multirow{3}{*}{$\begin{array}{c}\text { SA2003 } \\
(\text { EF547421) }\end{array}$} & & $100 \%(n=5)$ & \\
\hline & $\mathrm{IM}$ & $10^{3} \mathrm{MICLD}_{50}$ & & & $20 \%(n=5)$ & \\
\hline & $\mathrm{IM}$ & $10^{6} \mathrm{MICLD}_{50}$ & & & $20 \%(n=5)$ & \\
\hline & IC & $10^{2} \mathrm{MICLD}_{50}$ & \multirow{3}{*}{$\begin{array}{c}\text { SA2006 } \\
(\text { EF547422) }\end{array}$} & & $100 \%(n=5)$ & \\
\hline & $\mathrm{IM}$ & $10^{3} \mathrm{MICLD}_{50}$ & & & $0 \%(n=5)$ & \\
\hline & IM & $10^{6} \mathrm{MICLD}_{50}$ & & & $20 \%(n=5)$ & \\
\hline \multirow{6}{*}{ Mice (BALB/c) } & \multirow{6}{*}{$\mathrm{IM}$} & $10^{3} \mathrm{TCID}_{50}$ & $\begin{array}{c}\text { SA2008 } \\
\text { (HM179509) }\end{array}$ & \multirow{6}{*}{$\begin{array}{c}\text { Hind limb paralysis, ruffled } \\
\text { fur, weight loss, walking in } \\
\text { circles }\end{array}$} & $0 \%(n=4)$ & \multirow{6}{*}{ [17] } \\
\hline & & 105 & $\begin{array}{c}\text { SA2008 } \\
\text { (HM179509) }\end{array}$ & & $50 \%(n=4)$ & \\
\hline & & $10 \mathrm{CID} 50$ & $\begin{array}{c}\text { 8619NGA } \\
\text { (EU293110) }\end{array}$ & & $0 \%(n=4)$ & \\
\hline & & $10^{7} \mathrm{TCID}_{50}$ & $\begin{array}{c}\text { SA2004 } \\
\text { (EF547458) }\end{array}$ & & $60 \%(n=5)$ & \\
\hline & & $10^{8} \mathrm{TCID}_{50}$ & $\begin{array}{c}\text { Mong2004 } \\
\text { (DQ499948) }\end{array}$ & & $40 \%(n=5)$ & \\
\hline & & $10^{8} \mathrm{TCID}_{50}$ & $\begin{array}{c}\text { Afr1999 } \\
\text { (EF547447) }\end{array}$ & & $80 \%(n=5)$ & \\
\hline \multirow{3}{*}{ Eidolon helvum } & \multirow{3}{*}{ IC } & \multirow{3}{*}{$10^{3.5} \mathrm{TCID}_{50}$} & $\begin{array}{c}\text { 0406SEN } \\
\text { (EU293108) }\end{array}$ & \multirow{3}{*}{$\begin{array}{l}\text { Hindleg paresis, muscle } \\
\text { spasms, hyperaesthesia, } \\
\text { foam around mouth, } \\
\text { anorexia }\end{array}$} & $100 \%(n=3)$ & \multirow{3}{*}{ [64] } \\
\hline & & & $\begin{array}{c}\text { 8619NGA } \\
\text { (EU293110) }\end{array}$ & & $100 \%(n=3)$ & \\
\hline & & & $\begin{array}{c}31225 \\
\text { (LN849915) }\end{array}$ & & $100 \%(n=3)$ & \\
\hline
\end{tabular}


Table 6. Cont

\begin{tabular}{|c|c|c|c|c|c|c|}
\hline Host & Route1 & Dose & Isolate & Clinical Signs & Mortality & Reference \\
\hline \multirow{5}{*}{ Eidolon helvum } & \multirow{5}{*}{ IM } & $10^{0.1}$ TCID $_{50}$ & \multirow{5}{*}{$\begin{array}{c}31225 \\
(\mathrm{LN} 849915)\end{array}$} & No clinical signs & $25 \%(n=4)$ & \multirow{5}{*}{ [63] } \\
\hline & & $10^{1.1} \mathrm{TCID}_{50}$ & & \multirow{4}{*}{$\begin{array}{l}\text { Vocalization, muscle spasms, } \\
\text { salivation, aggression }\end{array}$} & $50 \%(n=4)$ & \\
\hline & & $10^{2.1} \mathrm{TCID}_{50}$ & & & $100 \%(n=4)$ & \\
\hline & & $10^{3.1}$ TCID $_{50}$ & & & $50 \%(n=4)$ & \\
\hline & & $10^{4.1} \mathrm{TCID}_{50}$ & & & $50 \%(n=4)$ & \\
\hline
\end{tabular}

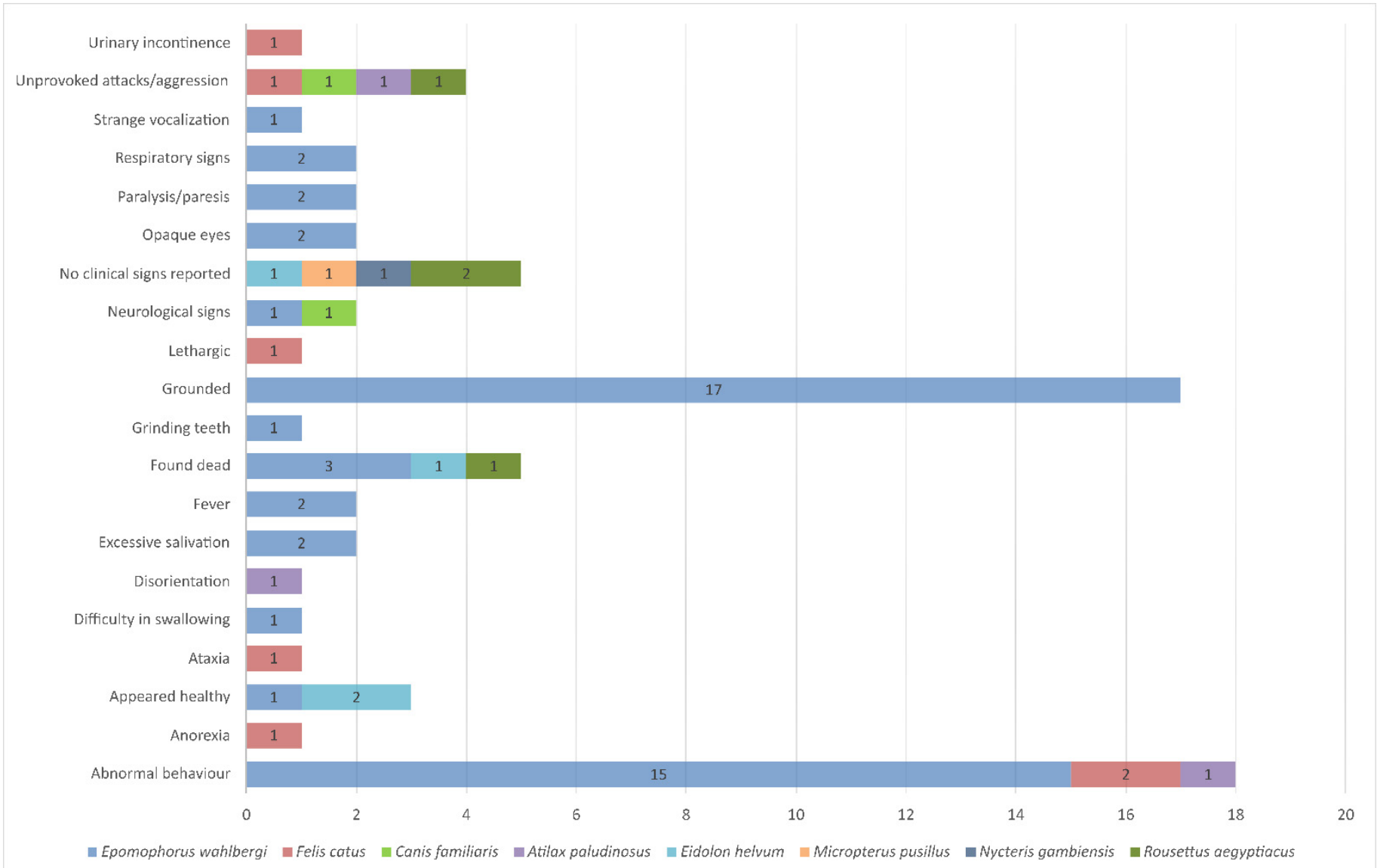

Figure 5. Reported clinical signs for animals naturally infected with Lagos bat virus.

\section{Prevention}

Commercial rabies biologics (rabies immunoglobulin (RIG) and vaccines) are based on RABV [65], and it is essential to assess their efficacy against other lyssaviruses, including LBV. Protection against disease development following exposure is reliant on both the innate (i.e., the basic immune system that induces non-specific resistance to disease) and the adaptive immune responses (i.e., highly specialized and systemic process). The presence of VNAs has been shown to be essential for protection against a productive infection [63, 66]. Initial neutralization tests in mice indicated that limited cross-reactivity occurs for LBV and that rabies vaccines might not confer protection $[7,8]$. This conclusion was further supported by additional studies showing that sera obtained from rabies-vaccinated people demonstrated significantly less neutralizing activity against LBV compared to viruses of phylogroup I [41,67]. This lack of protection against LBV has also been noted in a challenge study performed in mice [68] in addition to LBV infections reported in previously vaccinated domestic animals $[15,27,28]$. The titre of VNAs above a certain 
threshold is usually interpreted as indicative of protective immunity. Based on current data, the VNAs produced following rabies vaccines will likely not be protective against LBV infection. However, it has been suggested that several other components of the immune response (that is currently not completely understood or characterized) may play an important role in protection in addition to VNAs [69]. No human LBV cases have been reported to date; however, there is a potential spillover risk, since several human exposures have been associated with animals infected with LBV. Human rabies in Africa is also underestimated, frequently misdiagnosed and has limited diagnostic capacity on the continent, not often typed or molecularly characterized [70-73], and may simply have been missed. Additional treatment options, such as updated vaccines and alternatives to rabies immunoglobulin, should target a broader diversity of lyssaviruses [74,75]. Several strategies and potential pan-lyssavirus vaccines have been formulated. However, due to some inherent limitations (such as safety concerns, associated costs, inadequate immune responses and efficacy), a suitable alternative to the current rabies vaccines have not been established [74,76-79]. Public and veterinary health risks are suggested to be low, as demonstrated by the prevalence of infections in animals and humans. Since comprehensive data on the cross-reactivity of current biologicals are lacking, the cross-protection afforded by rabies biologicals is not known. As such, all bat exposures should be prioritized as category III exposures, as recommended by the World Health Organization (WHO), with post-exposure prophylaxis consisting of extensive and thorough washing of the wound, rabies immunoglobulin and vaccine administration [65].

\section{Conclusions}

Lagos bat virus is a unique endemic African lyssavirus, and detections remain rare and sporadic, mostly linked to where specific surveillance programs have been implemented. Surveillance efforts usually include only limited species diversity, mainly focused on those species previously implicated in infection. Viral nucleic acid detection has indicated an association of LBV with specific bat species, predominantly frugivorous bats. LBV lineages also appear to be associated with particular bat species. Serological surveillance has implicated a much broader geographical and species range, highlighting the lack of surveillance. Lyssaviruses are neurotropic and only disseminate late in infection to other organs and potential excretions; however, virus shedding may be intermittent. As such, the most reliable sample for viral nucleic acid detection will be post-mortem brain material. Detection rates using this strategy are very low (below 1\%). Considering the vital part bats play in ecosystems, combined with reduced population sizes and increased habitat destruction [26,80], this suggests that a re-evaluation of surveillance initiatives is needed. Surveillance efforts to detect LBV (and other lyssaviruses) should not be focused on killing apparently healthy animals. It should instead target animals displaying abnormal behaviour or clinical signs suggestive of rabies.

Serology on serum collected from healthy bat populations can be used as a surveillance tool through non-destructive sampling to obtain an estimate of the circulating diversity in specific species in a geographical space. However, serological studies' inherent limitations, including the potential cross-reactivity of lyssaviruses, should be considered. Seroprevalence in natural bat populations is significantly higher than the rate of virus detection. Specific bat species are regarded as reservoirs of lyssavirus infection and can generate an antibody response after initial infection. This mechanism is still not understood and potentially attributed to an abortive infection outside the central nervous system [81]. Spillover infections of LBV have been reported in various animals, several that have been previously vaccinated against rabies. Although no human LBV infections have been reported, such a spillover infection is possible with several exposure events being described. Such spillover infections usually result in dead-end events with no onward transmission $[82,83]$. Several factors have been hypothesized to play a role in onward transmission, including the incubation period, virus titre present in saliva, inherent features of the viral lineage involved, virus-host interactions and phylogenetic distance between the reservoir and non-reservoir 
host $[83,84]$. Although our understanding of the influence and impact of these factors on virus transmission remain limited, it appears that shorter incubation periods and reduced viral titre in the salivary glands of non-reservoir hosts restrict onward transmission [84].

There is currently a lack of knowledge on the host-pathogen interactions at the level of the pathogen (i.e., LBV) and the host (i.e., bats). Our understanding of the LBV infection dynamics, factors and mechanisms necessary for LBV transmission and maintenance, spillover mechanisms and information regarding bat population dynamics remains incomplete. Only once surveillance efforts are aligned with bat ecology and conservation using a one-health approach can we begin to address these fundamental but inherently complicated questions.

Supplementary Materials: The following are available online at https:/ /www.mdpi.com/article/10 $.3390 / v 13040576 / s 1$, Table S1: Details of surveillance studies for lyssavirus nucleic acid detection in Africa; Table S2. Details of serological surveillance studies for Lagos bat virus in Africa; Table S3. Details of lyssavirus sequences used for phylogenetic analysis.

Author Contributions: Conceptualization, J.C., K.1.R. and W.M.; Methodology, J.C. and M.G.; Writing-Original Draft Preparation, J.C.; Writing-Review and Editing, J.C., M.G., K.1.R. and W.M.; Funding Acquisition, W.M. All authors have read and agreed to the published version of the manuscript.

Funding: This research is supported in part by the South African Research Chair Initiative (held by Wanda Markotter) of the Department of Science and Innovation and administered by the National Research Foundation of South Africa (UID: 98339). The National Research Foundation funded the equipment based at the DNA Sanger sequencing facility in the Faculty of Natural and Agricultural Sciences, University of Pretoria (UID: 78566).

Institutional Review Board Statement: This study was approved by the University of Pretoria Animal Ethics Committee (approval no. EC054-14) and additional research approval in terms of Section 20 of the Animal Disease Act (35 of 1984) of South Africa from the Department of Agriculture, Land Reform and Rural Development.

Informed Consent Statement: Not applicable.

Data Availability Statement: Data presented in this study is openly available at ncbi.nlm.nih.gov (accessed on 25 February 2021) and the supplementary material (Tables S1-S3).

Acknowledgments: We thank the students and staff of the Centre for Viral Zoonoses, University of Pretoria, for technical assistance during fieldwork. We also thank the bat rehabilitator community, the bat interest groups and provincial rabies diagnostic laboratories for the submission and testing of bats.

Conflicts of Interest: The authors declare no conflict of interest.

\section{References}

1. Boulger, L.R.; Porterfield, J.S. Isolation of a virus from Nigerian fruit bats. Trans. R. Soc. Trop. Med. Hyg. 1958, 52, 421-424. [CrossRef]

2. Markotter, W.; Coertse, J. Bat lyssaviruses. Sci. Tech. Rev. 2018, 37, 385-400. [CrossRef]

3. ICTV International Committee on Taxonomy of Viruses. Available online: https://talk.ictvonline.org/ (accessed on 23 February 2021).

4. Coertse, J.; Grobler, C.S.; Sabeta, C.T.; Seamark, E.C.J.; Kearney, T.; Paweska, J.T.; Markotter, W. Lyssaviruses in insectivorous bats, South Africa, 2003-2018. Emerg. Infect. Dis. 2020, 26, 3056-3060. [CrossRef]

5. Badrane, H.; Tordo, N. Host switching in lyssavirus history from the Chiroptera to the Carnivora Orders. J. Virol. 2001, 75, 8096-8104. [CrossRef]

6. Nel, L.H.; Rupprecht, C.E. Emergence of lyssaviruses in the Old World: The case of Africa. In Wildlife and Emerging Zoonotic Diseases: The biology, Circumstances and Consequences of Cross-Species Transmission; Springer: Berlin/Heidelberg, Germany, 2007; Volume 1, pp. 161-193.

7. Shope, R.E. Rabies-related viruses. Yale J. Biol. Med. 1982, 55, 271-275.

8. Shope, R.E.; Murphy, F.A.; Harrison, A.K.; Causey, O.R.; Kemp, G.E.; Simpson, D.I.H.; Moore, D.L. Two African viruses serologically and morphologically related to rabies virus. J. Virol. 1970, 6, 690-692. [CrossRef] 
9. Swanepoel, R.; Barnard, B.J.; Meredith, C.D.; Bishop, G.C.; Brückner, G.K.; Foggin, C.M.; Hübschle, O.J. Rabies in southern Africa. Onderstepoort J. Vet. Res. 1993, 60, 325-346.

10. Kuzmin, I.V.; Niezgoda, M.; Franka, R.; Agwanda, B.; Markotter, W.; Beagley, J.C.; Urazova, O.Y.; Breiman, R.F.; Rupprecht, C.E. Lagos bat virus in Kenya. J. Clin. Microbiol. 2008, 46, 1451-1461. [CrossRef]

11. Freuling, C.M.; Binger, T.; Beer, M.; Adu-Sarkodie, Y.; Schatz, J.; Fischer, M.; Hanke, D.; Hoffmann, B.; Höper, D.; Mettenleiter, T.C.; et al. Lagos bat virus transmission in an Eidolon helvum bat colony, Ghana. Virus Res. 2015, 210, 42-45. [CrossRef]

12. Meredith, C.D.; Standing, E. Lagos bat virus in South Africa. Lancet 1981, 317, 832-833. [CrossRef]

13. Crick, J.; Tignor, G.H.; Moreno, K. A new isolate of Lagos bat virus from the Republic of South Africa. Trans. R. Soc. Trop. Med. Hyg. 1982, 76, 211-213. [CrossRef]

14. Markotter, W.; Randles, J.; Rupprecht, C.E.; Sabeta, C.T.; Taylor, P.J.; Wandeler, A.I.; Nel, L.H. Lagos bat virus, South Africa. Emerg. Infect. Dis. 2006, 12, 504-506. [CrossRef]

15. Markotter, W. Molecular Epidemiology and Pathogenesis of Lagos Bat Virus, a Rabies-Related Virus Specific to Africa; University of Pretoria: Pretoria, South Africa, 2007.

16. Markotter, W.; Kuzmin, I.; Rupprecht, C.E.; Nel, L.H. Phylogeny of Lagos bat virus: Challenges for lyssavirus taxonomy. Virus Res. 2008, 135, 10-21. [CrossRef]

17. Kgaladi, J.; Nel, L.H.; Markotter, W. Comparison of pathogenic domains of rabies and African rabies-related lyssaviruses and pathogenicity observed in mice. Onderstepoort J. Vet. Res. 2013, 80. [CrossRef] [PubMed]

18. Aubert, M.F.A. Rabies in individual countries. France. WHO Rabies Bull. Eur. 1999, Second Qua, 6.

19. Aubert, M.F.A. Rabies in individual countries. France. WHO Rabies Bull. Eur. 1999, Third quar, 5.

20. Kuzmin, I.V.; Markotter, W.; Agwanda, B.; Niezgoda, M.; Gilbert, A.T.; Rupprecht, C.E. Egyptian Fruit Bat (Rousettus aegyptiacus) as the Host of a Specific Lineage of Lagos Bat Virus in Kenya. Available online: https://www.researchgate.net/publication/3281 27074 (accessed on 25 February 2021).

21. Kuzmin, I.V.; Mayer, A.E.; Niezgoda, M.; Markotter, W.; Agwanda, B.; Breiman, R.F.; Rupprecht, C.E. Shimoni bat virus, a new representative of the Lyssavirus genus. Virus Res. 2010, 149, 197-210. [CrossRef]

22. Kuzmin, I.V.; Rupprecht, C. Bat lyssaviruses. In Bats and Viruses: A New Frontier of Emerging Infectious Diseases; Wang, L.-F., Cowled, C., Eds.; Wiley: Hoboken, NJ, USA, 2015; pp. 47-97. ISBN 9781118818824.

23. van Cakenberghe, V.; Seamark, E.C. (Eds.) African Chiroptera Report; AfricanBats NPC: Pretoria, South Africa, 2020; ISBN 9780323609845.

24. Sureau, P.; Germain, M.; Herve, J.P.; Geoffroy, B.; Cornet, J.P.; Heme, G.; Robin, Y. Isolation of the Lagos-bat virus in the Central African Republic. Bull. Soc. Pathol. Exot. Fil. 1977, 70, 467-470.

25. Sureau, P.; Tignor, G.H.; Smith, A.L. Antigenic characterization of the Bangui strain (ANCB-672d) of Lagos bat virus. Ann. l'Institut Pasteur Virol. 1980, 131, 25-32. [CrossRef]

26. Markotter, W.; Coertse, J.; de Vries, L.; Geldenhuys, M.; Mortlock, M. Bat-borne viruses in Africa: A critical review. J. Zool. 2020, 311,77-98. [CrossRef]

27. King, A.; Crick, J. Rabies-related viruses. In Rabies. Developments in Veterinary Virology; Campbell, J.B., Charlton, K.M., Eds.; Springer: Boston, MA, USA, 1988; pp. 177-199.

28. Foggin, C.M. Rabies and Rabies-Related Viruses in Zimbabwe: Historical, Virological and Ecological Aspects; University of Zimbabwe: Harare, Zimbabwe, 1988.

29. Mebatsion, T.; Cox, J.H.; Frost, J.W. Isolation and characterization of 115 street rabies virus isolates from Ethiopia by using monoclonal antibodies: Identification of 2 isolates as Mokola and Lagos bat viruses. J. Infect. Dis. 1992, 166, 972-977. [CrossRef] [PubMed]

30. Markotter, W.; Kuzmin, I.; Rupprecht, C.; Randles, J.; Sabeta, C.; Wandeler, A.; Nel, L. Isolation of Lagos Bat Virus from water mongoose. Emerg. Infect. Dis. 2006, 12, 1913-1918. [CrossRef]

31. Coertse, J.; Weyer, J.; Nel, L.H.; Markotter, W. Improved PCR methods for detection of African rabies and rabies-related lyssaviruses. J. Clin. Microbiol. 2010, 48, 3949-3955. [CrossRef] [PubMed]

32. Coertse, J.; Markotter, W.; le Roux, K.; Stewart, D.; Sabeta, C.T.; Nel, L.H. New isolations of the rabies-related Mokola virus from South Africa. BMC Vet. Res. 2016, 13, 37. [CrossRef] [PubMed]

33. Coertse, J. Is Mokola Virus the Most Recent Known Lyssavirus Ancestor of an Insect Virus Progenitor? In Insights from Cell Culture Studies and Molecular Surveillance; University of Pretoria: Pretoria, South Africa, 2015.

34. Coertse, J.; Weyer, J.; Nel, L.H.; Markotter, W. Reverse transcription recombinase polymerase amplification assay for rapid detection of canine associated rabies virus in Africa. PLoS ONE 2019, 14, e219292. [CrossRef] [PubMed]

35. Monadjem, A.; Demos, T.C.; Dalton, D.L.; Webala, P.W.; Musila, S.; Kerbis Peterhans, J.C.; Patterson, B.D. A revision of pipistrellelike bats (Mammalia: Chiroptera: Vespertilionidae) in East Africa with the description of new genera and species. Zool. J. Linn. Soc. 2020. [CrossRef]

36. Smith, T.; Gilbert, A. Comparison of a micro-neutralization test with the rapid fluorescent focus inhibition test for measuring rabies virus neutralizing antibodies. Trop. Med. Infect. Dis. 2017, 2, 24. [CrossRef]

37. Gilbert, A.T.; Fooks, A.R.; Hayman, D.T.S.; Horton, D.L.; Müller, T.; Plowright, R.; Peel, A.J.; Bowen, R.; Wood, J.L.N.; Mills, J.; et al. Deciphering serology to understand the ecology of infectious diseases in wildlife. Ecohealth 2013, 10, 298-313. [CrossRef] 
38. Mélade, J.; McCulloch, S.; Ramasindrazana, B.; Lagadec, E.; Turpin, M.; Pascalis, H.; Goodman, S.M.; Markotter, W.; Dellagi, K. Serological evidence of lyssaviruses among bats on Southwestern Indian Ocean Islands. PLoS ONE 2016, 11, e0160553. [CrossRef]

39. Badrane, H.; Bahloul, C.; Perrin, P.; Tordo, N. Evidence of two lyssavirus phylogroups with distinct pathogenicity and immunogenicity. J. Virol. 2001, 75, 3268-3276. [CrossRef]

40. Horton, D.L.; McElhinney, L.M.; Marston, D.A.; Wood, J.L.N.; Russell, C.A.; Lewis, N.; Kuzmin, I.V.; Fouchier, R.A.M.; Osterhaus, A.D.M.E.; Fooks, A.R.; et al. Quantifying antigenic relationships among the lyssaviruses. J. Virol. 2010, 84, 11841-11848. [CrossRef] [PubMed]

41. Hanlon, C.A.; Kuzmin, I.V.; Blanton, J.D.; Weldon, W.C.; Manangan, J.S.; Rupprecht, C.E. Efficacy of rabies biologics against new lyssaviruses from Eurasia. Virus Res. 2005, 111, 44-54. [CrossRef] [PubMed]

42. Hayman, D.T.S.; Fooks, A.R.; Horton, D.; Suu-Ire, R.; Breed, A.C.; Cunningham, A.A.; Wood, J.L.N. Antibodies against Lagos Bat Virus in Megachiroptera from West Africa. Emerg. Infect. Dis. 2008, 14, 926-928. [CrossRef]

43. Wright, E.; Hayman, D.T.S.; Vaughan, A.; Temperton, N.J.; Wood, J.L.N.; Cunningham, A.A.; Suu-Ire, R.; Weiss, R.A.; Fooks, A.R. Virus neutralising activity of African fruit bat (Eidolon helvum) sera against emerging lyssaviruses. Virology 2010, 408, 183-189. [CrossRef]

44. Dietzschold, B.; Rupprecht, C.E.; Tollis, M.; Lafon, M.; Mattei, J.; Wiktor, T.J.; Koprowski, H. Antigenic diversity of the glycoprotein and nucleocapsid proteins of rabies and rabies-related viruses: Implications for epidemiology and control of rabies. Clin. Infect. Dis. 1988, 10, S785-S798. [CrossRef]

45. Bourhy, H.; Kissi, B.; Tordo, N. Molecular diversity of the Lyssavirus genus. Virology 1993, 194, 70-81. [CrossRef]

46. Kissi, B.; Tordo, N.; Bourhy, H. Genetic polymorphism in the rabies virus nucleoprotein gene. Virology 1995, $209,526-537$. [CrossRef]

47. Delmas, O.; Holmes, E.C.; Talbi, C.; Larrous, F.; Dacheux, L.; Bouchier, C.; Bourhy, H. Genomic diversity and evolution of the lyssaviruses. PLOS ONE 2008, 3, e2057. [CrossRef]

48. Tignor, G.H.; Shope, R.E.; Bhatt, P.N.; Percy, D.H. Experimental infection of dogs and monkeys with two rabies serogroup viruses, Lagos bat and Mokola (IbAn 27377): Clinical, serologic, virologic, and fluorescent-antibody studies. J. Infect. Dis. 1973, 128, 471-478. [CrossRef] [PubMed]

49. Markotter, W.; Kuzmin, I.V.; Rupprecht, C.E.; Nel, L.H. Lagos bat virus virulence in mice inoculated by the peripheral route. Epidemiol. Infect. 2009, 137, 1155-1162. [CrossRef] [PubMed]

50. Masatani, T.; Ito, N.; Shimizu, K.; Ito, Y.; Nakagawa, K.; Abe, M.; Yamaoka, S.; Sugiyama, M. Amino acids at positions 273 and 394 in rabies virus nucleoprotein are important for both evasion of host RIG-I-mediated antiviral response and pathogenicity. Virus Res. 2011, 155, 168-174. [CrossRef]

51. Poisson, N.; Real, E.; Gaudin, Y.; Vaney, M.-C.; King, S.; Jacob, Y.; Tordo, N.; Blondel, D. Molecular basis for the interaction between rabies virus phosphoprotein $\mathrm{P}$ and the dynein light chain LC8: Dissociation of dynein-binding properties and transcriptional functionality of P. J. Gen. Virol. 2001, 82, 2691-2696. [CrossRef]

52. Irie, T.; Carnero, E.; Okumura, A.; García-Sastre, A.; Harty, R.N. Modifications of the PSAP region of the matrix protein lead to attenuation of vesicular stomatitis virus in vitro and in vivo. J. Gen. Virol. 2007, 88, 2559-2567. [CrossRef]

53. Wirblich, C.; Tan, G.S.; Papaneri, A.; Godlewski, P.J.; Orenstein, J.M.; Harty, R.N.; Schnell, M.J. PPEY motif within the rabies virus (RV) matrix protein is essential for efficient virion release and RV pathogenicity. J. Virol. 2008, 82, 9730-9738. [CrossRef]

54. Gholami, A.; Kassis, R.; Real, E.; Delmas, O.; Guadagnini, S.; Larrous, F.; Obach, D.; Prevost, M.-C.; Jacob, Y.; Bourhy, H. Mitochondrial dysfunction in lyssavirus-induced apoptosis. J. Virol. 2008, 82, 4774-4784. [CrossRef]

55. Mita, T.; Shimizu, K.; Ito, N.; Yamada, K.; Ito, Y.; Sugiyama, M.; Minamoto, N. Amino acid at position 95 of the matrix protein is a cytopathic determinant of rabies virus. Virus Res. 2008, 137, 33-39. [CrossRef]

56. Prehaud, C.; Diallo, A.; Martient-Edelist, C.; Coulon, P.; Flamand, A. Characterization of a new temperature-sensitive and avirulent mutant of the rabies virus. Virus Res. 1988, 11, 88. [CrossRef]

57. Faber, M.; Pulmanausahakul, R.; Nagao, K.; Prosniak, M.; Rice, A.B.; Koprowski, H.; Schnell, M.J.; Dietzschold, B. Identification of viral genomic elements responsible for rabies virus neuroinvasiveness. Proc. Natl. Acad. Sci. USA 2004, 101, 16328-16332 [CrossRef]

58. Takayama-Ito, M.; Ito, N.; Yamada, K.; Sugiyama, M.; Minamoto, N. Multiple amino acids in the glycoprotein of rabies virus are responsible for pathogenicity in adult mice. Virus Res. 2006, 115, 169-175. [CrossRef]

59. Langevin, C.; Jaaro, H.; Bressanelli, S.; Fainzilber, M.; Tuffereau, C. Rabies virus glycoprotein (RVG) is a trimeric ligand for the N-terminal cysteine-rich domain of the mammalian p75 neurotrophin receptor. J. Biol. Chem. 2002, 277, 37655-37662. [CrossRef] [PubMed]

60. Coulon, P.; Ternaux, J.-P.; Flamand, A.; Tuffereau, C. An avirulent mutant of rabies virus is unable to infect motoneurons in vivo and in vitro. J. Virol. 1998, 72, 273-278. [CrossRef]

61. Dietzschold, B.; Wunner, W.H.; Wiktor, T.J.; Lopes, A.D.; Lafon, M.; Smith, C.L.; Koprowski, H. Characterization of an antigenic determinant of the glycoprotein that correlates with pathogenicity of rabies virus. Proc. Natl. Acad. Sci. USA 1983, 80, 70-74. [CrossRef]

62. Tuffereau, C.; Benejean, J.; Blondel, D.; Kieffer, B.; Flamand, A. Low-affinity nerve-growth factor receptor (P75NTR) can serve as a receptor for rabies virus. EMBO J. 1998, 17, 7250-7259. [CrossRef] 
63. Begeman, L.; Suu-Ire, R.; Banyard, A.C.; Drosten, C.; Eggerbauer, E.; Freuling, C.M.; Gibson, L.; Goharriz, H.; Horton, D.L.; Jennings, D.; et al. Experimental Lagos bat virus infection in straw-colored fruit bats: A suitable model for bat rabies in a natural reservoir species. PLoS Negl. Trop. Dis. 2020, 14, e0008898. [CrossRef]

64. Suu-Ire, R.; Fooks, A.; Banyard, A.; Selden, D.; Amponsah-Mensah, K.; Riesle, S.; Ziekah, M.; Ntiamoa-Baidu, Y.; Wood, J.; Cunningham, A. Lagos bat virus infection dynamics in free-ranging straw-colored fruit bats (Eidolon helvum). Trop. Med. Infect. Dis. 2017, 2, 25. [CrossRef]

65. World Health Organization. Rabies Vaccines: WHO Position Paper, April 2018-Recommendations. Vaccine 2018, 36, 5500-5503. [CrossRef] [PubMed]

66. Hooper, D.C.; Morimoto, K.; Bette, M.; Weihe, E.; Koprowski, H.; Dietzschold, B. Collaboration of antibody and inflammation in clearance of rabies virus from the central nervous system. J. Virol. 1998, 72, 3711-3719. [CrossRef]

67. Malerczyk, C.; Freuling, C.; Gniel, D.; Giesen, A.; Selhorst, T.; Müller, T. Cross-neutralization of antibodies induced by vaccination with Purified Chick Embryo Cell Vaccine (PCECV) against different Lyssavirus species. Hum. Vaccin. Immunother. 2014, 10, 2799-2804. [CrossRef] [PubMed]

68. Fekadu, M.; Shaddock, J.; Sanderlin, D.; Smith, J. Efficacy of rabies vaccines against Duvenhage virus isolated from European house bats (Eptesicus serotinus), classic rabies and rabies-related viruses. Vaccine 1988, 6, 533-539. [CrossRef]

69. Overduin, L.A.; van Dongen, J.J.; Visser, L.G.; Dongen, V. The cellular immune response to rabies vaccination: A systematic review. Vaccines 2019, 7, 110. [CrossRef]

70. Mallewa, M.; Fooks, A.R.; Banda, D.; Chikungwa, P.; Mankhambo, L.; Molyneux, E.; Molyneux, M.E.; Solomon, T. Rabies encephalitis in malaria-endemic area, Malawi, Africa. Emerg. Infect. Dis. 2007, 13, 136-139. [CrossRef] [PubMed]

71. Weyer, J.; Dermaux-Msimang, V.; Grobbelaar, A.; le Roux, C.; Moolla, N.; Paweska, J.; Blumberg, L. Epidemiology of human rabies in South Africa, 2008-2018. S. Afr. Med. J. 2020, 110, 877. [CrossRef]

72. Hampson, K.; Coudeville, L.; Lembo, T.; Sambo, M.; Kieffer, A.; Attlan, M.; Barrat, J.; Blanton, J.D.; Briggs, D.J.; Cleaveland, S.; et al. Estimating the global burden of endemic canine rabies. PLoS Negl. Trop. Dis. 2015, 9, e0003709. [CrossRef]

73. Rupprecht, C.E.; Kuzmin, I.V.; Yale, G.; Nagarajan, T.; Meslin, F.-X. Priorities in applied research to ensure programmatic success in the global elimination of canine rabies. Vaccine 2019, 37, A77-A84. [CrossRef]

74. Weyer, J.; Kuzmin, I.V.; Rupprecht, C.E.; Nel, L.H. Cross-protective and cross-reactive immune responses to recombinant vaccinia viruses expressing full-length lyssavirus glycoprotein genes. Epidemiol. Infect. 2008, 136, 670-678. [CrossRef]

75. Fisher, C.R.; Lowe, D.E.; Smith, T.G.; Yang, Y.; Hutson, C.L.; Wirblich, C.; Cingolani, G.; Schnell, M.J. Lyssavirus vaccine with a chimeric glycoprotein protects across phylogroups. Cell Rep. 2020, 32, 107920. [CrossRef]

76. Evans, J.S.; Horton, D.L.; Easton, A.J.; Fooks, A.R.; Banyard, A.C. Rabies virus vaccines: Is there a need for a pan-lyssavirus vaccine? Vaccine 2012, 30, 7447-7454. [CrossRef]

77. Jallet, C.; Jacob, Y.; Bahloul, C.; Drings, A.; Desmezieres, E.; Tordo, N.; Perrin, P. Chimeric lyssavirus glycoproteins with increased immunological potential. J. Virol. 1999, 73, 225-233. [CrossRef]

78. Kgaladi, J.; Faber, M.; Dietzschold, B.; Nel, L.; Markotter, W. Pathogenicity and immunogenicity of recombinant rabies viruses expressing the Lagos bat virus matrix and glycoprotein: Perspectives for a pan-lyssavirus vaccine. Trop. Med. Infect. Dis. 2017, 2, 37. [CrossRef]

79. Nel, L.; Niezgoda, M.; Hanlon, C.; Morril, P.; Yager, P.; Rupprecht, C. A comparison of DNA vaccines for the rabies-related virus, Mokola. Vaccine 2003, 21, 2598-2606. [CrossRef]

80. Olival, K.J. To cull, or not to cull, bat is the question. Ecohealth 2016, 13, 6-8. [CrossRef] [PubMed]

81. Banyard, A.; Evans, J.; Luo, T.; Fooks, A. Lyssaviruses and bats: Emergence and zoonotic threat. Viruses 2014, 6, 2974-2990. [CrossRef]

82. Rupprecht, C.; Kuzmin, I.; Meslin, F. Lyssaviruses and rabies: Current conundrums, concerns, contradictions and controversies. F1000Research 2017, 6, 184. [CrossRef] [PubMed]

83. Streicker, D.G.; Turmelle, A.S.; Vonhof, M.J.; Kuzmin, I.V.; McCracken, G.F.; Rupprecht, C.E. Host Phylogeny Constrains Cross-Species Emergence and Establishment of Rabies Virus in Bats. Science 2010, 329, 676-679. [CrossRef]

84. Mollentze, N.; Streicker, D.G.; Murcia, P.R.; Hampson, K.; Biek, R. Virulence mismatches in index hosts shape the outcomes of cross-species transmission. Proc. Natl. Acad. Sci. USA 2020, 117, 28859-28866. [CrossRef] 